\title{
Why the renin-angiotensin-aldosterone system (RAAS) in critically ill patients can no longer be ignored
}

\author{
Alexander Zarbock ${ }^{*^{*}}$ (D) Lakhmir Chawla ${ }^{2}$ and Rinaldo Bellomo 3,4,5
}

\section{Background}

Vasodilatory shock is a common form of shock, characterized by preserved or increased cardiac output and peripheral vasodilation. Inflammatory syndromes or states, such as sepsis and major surgery, are common causes of vasodilatory shock. Acute kidney injury (AKI) is a common complication of a vasodilatory shock and is associated with increased mortality [1]. Sepsis is the most common cause of AKI [2]. The pathophysiology of vasoplegia is complex and not fully understood, but different hormonal systems are involved in the regulation of systemic vascular resistance, including the renin-angiotensin-aldosterone system (RAAS).

The RAAS contributes to the control of blood pressure, fluid homeostasis, electrolyte balance, and glomerular filtration rate [3]. Renin cleaves angiotensinogen to angiotensin (AT)-I and this precursor is then cleaved to produce AT-II by the angiotensin converting enzyme (ACE). High AT-II levels produce vasoconstriction, stimulate the adrenal gland to release aldosterone and, in turn, inhibit renin generation by biofeedback. Conversely, if AT-IIgeneration is impaired renin-levels will rise in an attempt to generate more AT-II precursor.

In a recent study, Flannery and colleagues [4] demonstrated that elevated renin-levels in critically ill patients are associated with worse outcomes. In a multicenter

\footnotetext{
*Correspondence: zarbock@uni-muenster.de

${ }^{1}$ Department of Anaesthesiology, Intensive Care and Pain Medicine,

University Hospital Münster, Albert-Schweitzer-Campus 1, Geb. A1, 48149 Munster, Germany

Full list of author information is available at the end of the article
}

study, the authors included critically ill patients with (at least stage 2) or without AKI. The primary outcome was the composite endpoint of major adverse kidney events (MAKE) at hospital discharge, consisting of mortality, kidney replacement therapy, or reduced estimated glomerular filtration rate to $\leq 75 \%$ of baseline. The MAKE rate was twice as high in patients in the top renin-tertile compared with the bottom renin-tertile, mortality was three fold greater and the use of kidney replacement therapy was four-fold greater. On multivariable logistic regression analysis, renin-levels remained significantly associated with MAKE. However, the authors were unable to adjusted renin-levels for the recent intake of ACE inhibitors or ARBs and did not report on reninlevels according to the presence of vasodilatory shock. Nonetheless, patients in the upper tertile of renin-levels received more vasopressor drugs at baseline $(P<0.001)$.

These findings are in line with previous work also showing that elevated renin-levels are associated with an increased mortality [5]. In this post-hoc analysis, the authors demonstrated that renin-levels are commonly elevated in patients with catecholamine-resistant vasodilatory shock. Moreover, they found that reninlevels correlated with the AT-I/AT-II ratio, which was also increased [5]. The underlying cause of this finding might be related to ACE-dysfunction or increased AT-II degradation by neutral endopeptidase. The inflammatory response, which accompanies critical illness, however, causes a reduced ACE-activity. This reduction may subsequently lead to decreased conversion of AT-I to AT-II [5] which will likely lead to persistent hypotension and high renin-levels. Similar to this, a recent study

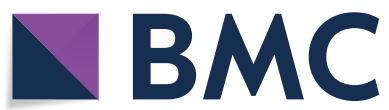

C The Author(s) 2021. Open Access This article is licensed under a Creative Commons Attribution 4.0 International License, which permits use, sharing, adaptation, distribution and reproduction in any medium or format, as long as you give appropriate credit to the original author(s) and the source, provide a link to the Creative Commons licence, and indicate if changes were made. The images or other third party material in this article are included in the article's Creative Commons licence, unless indicated otherwise in a credit line to the material. If material is not included in the article's Creative Commons licence and your intended use is not permitted by statutory regulation or exceeds the permitted use, you will need to obtain permission directly from the copyright holder. To view a copy of this licence, visit http://creativecommons.org/licenses/by/4.0/. The Creative Commons Public Domain Dedication waiver (http://creativecommons.org/publicdomain/zero/1.0/) applies to the data made available in this article, unless otherwise stated in a credit line to the data. 
has suggested that an imbalance in the RAAS may be involved in COVID-19-pathophysiology [6].

Absolute or relative AT-II deficiency can now be addressed by administering exogenous AT-II. Compared with placebo, this approach reduced 28-day-mortality in patients with a catecholamine-resistent vasodilatory shock and high renin-levels [5]. Based on the available evidence, it can be hypothesized that individualized treatment of patients with vasodilatory shock and elevated renin-levels with exogenous AT-II can improve patient-centered outcomes including survival. Renin measurement is inexpensive and a widely available test.

These considerations may be relevant to cardiac-surgery patients. Kullmar and colleagues [7] showed that a hyperreninemia after cardiac-surgery was associated with a cardiovascular instability and an AKI, but not with an increased mortality. Although Kullmar's study was affected by limited power because of the low mortality rate, the discrepancy between both studies may also relate to the time points of renin measurements. Kullmar and colleagues measured the renin-levels early after surgery, whereas Flannery and colleagues measured the concentrations once an AKI was present. These observations suggest that elevated renin-levels during the course of a disease might be induced by different causes and may be associated with different outcomes. It is possible, for example, that early increases in renin-levels are primarily caused by reduced ACE-activity, whereas elevated reninlevels seen at a later stage of the disease may be caused by an inadequate activation of the ATR1-receptor. Future research should focus on the nature and causes of AT-II deficiency.

High renin-levels portend a worse outcome and outperform lactate as prognostic indicator of survival $[8,9]$. Thus, the notion of a high-renin biotype is becoming increasingly supported by evidence and, given the availability of AT-II, is now clinically relevant [5]. An important additional consideration is the etiology of such elevated renin state. The renin-levels seen in shocked patients exceed levels seen in renin-secreting tumors, which suggests a broad RAAS response. Moreover, since these elevated renin-levels are seen in both severe AKI and ESRD, it is likely that the kidney is not the sole source of renin as this hormone can be secreted from various non-renal sources $[5,10]$. This raises the question as to whether patients with high-renin shock have hyperreninemia because of decreased AT-II production or because of decreased ATR1 responsiveness or both or even because of other mechanism [11]. This question cannot yet be answered. However, we know that, in patients with vasodilatory shock, secondary hyperreninemia renin is decreased when AT-II is administered [5]. Additionally, experimental models of sepsis suggest that decreased AT1R-responsiveness may also be important and contribute to kidney injury [12]. Clearly, renewed interest in the RAAS during critical illness demands more sophisticated analyses of all aspects of this system not only at baseline but also over time and in response to interventions.

\section{Conclusions}

There are profound and clinically relevant disturbances of the RAAS in critically ill patients, detected by the presence of hyperreninemia. Depending on the time of renin measurement and the population, this hormone may be associated with the development of AKI or an increased mortality or both. In addition, the vasodilatory biotype of high-renin shock may, in the future, be further defined by the mechanisms responsible for hyperreninemia. Irrespective of the mechanisms, however, personalized treatment of critically ill patients who have high renin-levels with AT-II might improve outcome. The importance and complexity of the RASS in critical illness can no longer be ignored.

\section{Acknowledgements}

Not applicable.

\section{Authors' contributions}

All authors wrote, revised and approved the final manuscript.

\section{Funding}

This work was supported by the DFG (KFO342-1, ZA428/18-1, and ZA428/21-1 to A.Z.)

\section{Availability of data and materials}

Not applicable.

\section{Declarations}

Ethical approval and consent to participate Not applicable.

\section{Consent for publication}

Not applicable.

Competing interests

The authors declare that they have no competing interests.

\section{Author details}

${ }^{1}$ Department of Anaesthesiology, Intensive Care and Pain Medicine, University Hospital Münster, Albert-Schweitzer-Campus 1, Geb. A1, 48149 Munster, Germany. ${ }^{2}$ Veterans Affairs Medical Center, San Diego, CA, USA. ${ }^{3}$ Department of Critical Care, The University of Melbourne, Melbourne, Australia. ${ }^{4}$ Department of Intensive Care, Royal Melbourne Hospital, Parkville, VIC, Australia. ${ }^{5}$ Department of Intensive Care, Austin Health, Heidelberg, Australia. ${ }^{6}$ Australian and New Zealand Intensive Care Research Centre, School of Public Health and Preventive Medicine, Monash University, Melbourne, Australia.

Received: 24 Auqust 2021 Accepted: 4 November 2021

Published online: 14 November 2021

\section{References}

1. Joannidis M, Druml W, Forni LG, Groeneveld ABJ, Honore PM, Hoste E, Ostermann M, Oudemans-van Straaten HM, Schetz M. Prevention of acute kidney injury and protection of renal function in the intensive care unit: update 2017: expert opinion of the Working Group on Prevention, 
AKI section, European Society of Intensive Care Medicine. Intensive Care Med. 2017:43(6):730-49.

2. Uchino S, Kellum JA, Bellomo R, Doig GS, Morimatsu H, Morgera S, Schetz M, Tan I, Bouman C, Macedo E, et al. Acute renal failure in critically ill patients: a multinational, multicenter study. JAMA. 2005;294(7):813-8.

3. Chawla LS, Busse LW, Brasha-Mitchell E, Alotaibi Z. The use of angiotensin II in distributive shock. Crit Care. 2016;20(1):137.

4. Flannery AH, Ortiz-Soriano V, Li X, Gianella FG, Toto RD, Moe OW, Devarajan P, Goldstein SL, Neyra JA. Serum renin and major adverse kidney events in critically ill patients: a multicenter prospective study. Crit Care. 2021:25(1):294.

5. Bellomo R, Forni LG, Busse LW, McCurdy MT, Ham KR, Boldt DW, Hastbacka J, Khanna AK, Albertson TE, Tumlin J, et al. Renin and survival in patients given angiotensin ii for catecholamine-resistant vasodilatory shock: a clinical trial. Am J Respir Crit Care Med. 2020;202(9):1253-61.

6. Rysz S, Al-Saadi J, Sjostrom A, Farm M, Campoccia Jalde F, Platten M, Eriksson H, Klein M, Vargas-Paris R, Nyren S, et al. COVID-19 pathophysiology may be driven by an imbalance in the renin-angiotensin-aldosterone system. Nat Commun. 2021;12(1):2417.

7. Kullmar M, Saadat-Gilani K, Weiss R, Massoth C, Lagan A, Cortes MN, Gerss J, Chawla LS, Fliser D, Meersch M, et al. Kinetic changes of plasma renin concentrations predict acute kidney injury in cardiac surgery patients. Am J Respir Crit Care Med. 2021;203(9):1119-26.
8. Jeyaraju M, McCurdy MT, Levine AR, Devarajan P, Mazzeffi MA, Mullins KE, Reif M, Yim DN, Parrino C, Lankford AS, et al. Renin kinetics are superior to lactate kinetics for predicting in-hospital mortality in hypotensive critically ill patients. Crit Care Med. 2021.

9. Gleeson PJ, Crippa IA, Mongkolpun W, Cavicchi FZ, Van Meerhaeghe T, Brimioulle S, Taccone FS, Vincent JL, Creteur J. Renin as a marker of tissue-perfusion and prognosis in critically ill patients. Crit Care Med. 2019;47(2):152-8

10. Shaw I, Rider S, Mullins J, Hughes J, Peault B. Pericytes in the renal vasculature: roles in health and disease. Nat Rev Nephrol. 2018;14(8):521-34.

11. Chen L, Kim SM, Eisner C, Oppermann M, Huang Y, Mizel D, Li L, Chen M, Sequeira Lopez ML, Weinstein LS, et al. Stimulation of renin secretion by angiotensin II blockade is Gsalpha-dependent. J Am Soc Nephrol. 2010;21(6):986-92.

12. Leisman DE, Fernandes TD, Bijol V, Abraham MN, Lehman JR, Taylor MD, Capone C, Yaipan O, Bellomo R, Deutschman CS. Impaired angiotensin II type 1 receptor signaling contributes to sepsis-induced acute kidney injury. Kidney Int. 2021;99(1):148-60.

\section{Publisher's Note}

Springer Nature remains neutral with regard to jurisdictional claims in published maps and institutional affiliations.
Ready to submit your research? Choose BMC and benefit from:

- fast, convenient online submission

- thorough peer review by experienced researchers in your field

- rapid publication on acceptance

- support for research data, including large and complex data types

- gold Open Access which fosters wider collaboration and increased citations

- maximum visibility for your research: over $100 \mathrm{M}$ website views per year

At BMC, research is always in progress.

Learn more biomedcentral.com/submissions 